\title{
Evaluation of Governance Systems for Response and Recovery Measures During Flood Disaster in Niger State, Nigeria
}

\author{
Umar Tauheed Ibrahim (Ph.D.) \\ Department of Urban and Regional Planning, Enugu State University of science and Technology, Nigeria \\ Onoh, Felix Emenike \\ Department of Quantity Surveying, Enugu State University of Science and Technology, (ESUT), Enugu State \\ Nigeria \\ Joy Okereke \\ Department of Quantity Surveying, Enugu State University of Science and Technology, (ESUT), Enugu State \\ Nigeria
}

\begin{abstract}
Situated around the confluence of Niger and Benue Rivers, Niger State experiences annual flood episodes. The Niger, Benue and Gurara Rivers overspill their channels annually during the wet season thereby causing damages. If well planned, rescue and recovery processes should protect the lives and property of flood- prone areas, reduce vulnerability to flood hazards, safeguard the health of rescued people, promote social learning among affected persons by reoccurring floods and provide better understanding of the local economy to determine how different interventions may affect the local people. Against this backdrop, the study examined the rescue and recovery measures from Niger State flood disasters and the impacts of floods on the entire state. Specifically, the study seeks to identify formal and informal organizations involved in flood rescue and recovery measures during flood disasters in Niger state. This study was survey- based research and the data used for the study were collected from both primary and secondary sources. Two sets of questionnaire were used to obtain information. The first set centred on information concerning households on their perception of emergency institutional responses/ rescue operations during flood disasters in the study area while the second set of questionnaire were administered on both public and private emergency management institutions and agencies. In all, a total of six hundred (600) copies of questionnaire were administered in the twenty five (25) local government Areas of Niger State but five hundred and eight (582) copies were successfully completed and retrieved from the respondents. Statistical techniques used for data analysis and testing of hypotheses include the student T- test, Analysis of variance (ANOVA), Factor analysis, principal component analysis and Pearson correlation coefficient (PCC). The computer programme employed for the PCA was statistical package for social sciences (SPSS), version 20 for window The result of data analysis revealed that the rescue and recovery operations have a mean and standard deviation (SD) of 1.59+.492 indicating that the level of effectiveness in rescue and recovery measure during flooding were ineffective at 231(39.7\%) The study recommends the critical need for synergy between public and $\mathrm{NGO} / \mathrm{CBO}$ emergency management operation, improve the effectiveness and efficiency of rescue operations, maximize the use of available resources during flooding and devote more resources to the medical needs and restoration of livelihood activities of residents to enhance early recovery of normal life.
\end{abstract}

Keywords: Evaluation, Governance System, Response, Recovery, Flood Disaster, Niger State.

DOI: $10.7176 / \mathrm{JESD} / 11-22-11$

Publication date: November $30^{\text {th }} 2020$

\section{Introduction}

The number of people affected by climate related disaster is on the rise, particularly in low and middle-income countries where rapid urbanization is taking place (Adedeji, Odufuwa, Adebayo. 2012) and Umar, T. I. (2017). The trend in the frequency and intensity of disasters nationally and internationally is due to unpredictable climate changes, severe flooding, fire, drought, terrorism, epidemics and urbanization especially in developing countries Bell-Gam,(2000). With expected shifts in precipitation patterns, melting snow packs and glaciers, strong tropical cyclones, and a rising sea level, climate changes is becoming a risk multiplier for the poor and a core development challenge for developing and developed economies alike (Adedeji,2012). In response to this development, the Intergovernmental Panel on Climate Change (IPCC) Fourth Assessment Report (2007b) predicts that the heavy precipitation events, which are very likely to increase in frequency, will augment flood risks IPCC, (2007b).

Flood alone is a hazard but when it affects man and his properties or activities, it is called a disaster NEMA,(2012). Flood is a disaster because it results in: loss of lives, loss of agricultural products, loss of soil fertility for agriculture, and renders many homeless, destroys livestock and other valuable assets while causing 
cholera and other health related problems Ghosh, (2006b) and Umar T.I \& Oduwole O. (2017). Floods by nature are complex events caused by a range of human vulnerabilities, inappropriate development planning and climate variability (Ghosh,2006b). Flood can be predicted to a reasonable extent, with the exception of flash flood, whose scale and nature are often less certain. (UN, 2018;UNDP, 2004) and Umar, T.I.\& Ugwu, L. N.(2019). Over the past decades, the pattern of floods across all continents has been changing, becoming more frequent, intense and unpredictable for local communities, particularly as issues of development and poverty have led more people to live in areas vulnerable to flooding.

Nigeria in the last two decades has witnessed tremendous increase in the population of coastal areas, which place more people at the risk of extreme weather event Umar, T. I. (2017) indicates that serious flood disaster are known to have occurred in many areas including lbadan (1985, 1987, 1990, 2012), Osogbo, Osun State (1992, 1996, 2002, 2012), Yobe (1985, 1990, 2000, 2012), Akure (1996, 2000, 2002, 2004, 2006), Kogi State (2001, 2012, 2015, 2016), Niger State (1992, 1996, 2002, 2000, 2010, 2012, 2013, 2014, 2015, 2016). The coastal cities of Lagos, Port Harcourt, Calabar, Uyo and Warri are among many location with incidences that have claimed many lives and properties worth millions of naira (Eludoyin, Akinbode, Alabi, Okuku,2007 and Umar, T. I.\& Ihekwoaba, E.N.(2020)). Flood hazards are natural phenomena, but damage and losses from floods are mostly the consequence of human action (ALNAP and prevention,2008a).Urbanization aggravates flooding by restricting where flood waters can go. This results from covering large parts of the ground with roofs, roads and pavements thereby obstructing sections of natural channel and by building drains that ensure that water moves to rivers faster than it did under natural conditions, (Areola,1994; Akintola, 1974a; Oguntoyinbo, 1994). As more people crowd the cities, these effects intensify; as a result, just as moderate storms produce high flows in rivers because of the prevalence of hard surface and inadequate drains (ALNAP and Prevention, 2008b).

When floods exceed normal flooding level, they take dangerous turns (Adedeji, 2012).Floods are almost annual events in Nigeria. Many times in the history of Nigeria, floods took severe and sometimes catastrophic turn (Rhettibutler,2009). In the past five decades, economic losses due to natural hazards such as flood disasters have increased and have also resulted in major loss of human lives and livelihoods, the destruction of economic and social infrastructure, as well as environmental damages during this period (Bailey,1982, Faniran,1975, Faniran,1994, Hualou,2011).Many impacts of floods are similar to those of other disasters although their magnitude, nature and scale may vary and these impacts may be caused in different ways.

The impacts of floods on lives and livelihoods and the way agencies and individual have addressed them are similar in most parts of the world, (World Commission on Environment and Development) WCED,1987). The effectiveness of agency interventions has, however, always been conditioned by factors specific to the context and circumstances (ALNAP and Prevention, 2008a; ADPC and UNDP,2005). In areas where flooding occurs regularly, the community will probably be better prepared than people living in places where floods are rare. After the flood water begins to recede, the focus of relief efforts is on returning things to normal. Vulnerable people individually and collectively develop their own means, resources and strategies to cope with flooding. All of these mechanisms, however, have financial, social and/or opportunity costs (ALNAP and Prevention,2008b). For instance, during this phase, many historic structures and properties are needlessly lost and damaged through hasty clean-up procedures. In the same vein, organizational priorities, assumptions and beliefs, rather than the findings from an assessment, often shape the strategy and content of flood response( ALNAP and Prevention, 2008a).

The tendency for people after a natural disaster is to band together, ensuring that mutual trust can be maintained is important for effective reconstruction efforts. For example, the manner in which relief distributions are managed either enhances community involvement in reconstruction. (ALNAP and Prevention, 2008a).

Managing nationwide response and coordination are very germane for effective recovery after flood disaster. Yamin,(2007) argued that conflicts between formal and informal governance or governmental and nongovernmental strategies and norms can generate additional setback for communities exposed to environmental challenge. An example of these conflicts of formal and informal strategies is linked to flood protection measures. While local people might expend resources to deal with increasing flood events (e.g. adapting their livelihoods and production patterns to changing flood regimes).(GFDRR,2011). Particularly in developing countries, prioritize structure measures (e.g. dike systems or relocation strategies) that have severe consequences for the communities are dependent on local ecosystem services, such as fishing and farming systems. (Bakar,2012).

These conflicts call for comprehensive city-wide or nationwide coordination of response, relief and recovery activities. Coordination takes time and effort, but when done properly, it is time well spent. Under the United Nation's recently developed regime of 'cluster', key emergency sectors have lead agencies with responsibilities for coordination and delivery in case of last resort. The response to the Pakistan floods in 2007 was one of the first test cases for the clusters and highlighted the importance of streamlining coordination structures to facilitate engagement with local government and NGO partners (Jacobson et al,2012).

For effective coordination to be achieved there is need to educate the populace about the need and strategies for managing flood risk through local and collective adaptive measures. The education dimension ranges across 
sharing and access to disaster risk reduction and climate adaptation information and knowledge. (Jacobson, 2012).

A well-informed and motivated population can lead to disaster risk reduction but it requires the collection and dissemination of knowledge and information on hazards, vulnerabilities and capacities. (McCarthy et al,2001),.

\section{Statement of the Research Problem}

Umar, T. I. (2017) showed that flood had displaced over 500,000 people in Niger - state with over 300 communities in the various local government areas of Niger state including Lapai, Shiroro, Muyan, Gurara, Bida, Lavun, Wushishi, Mokwa and Borgu have been affected with hundreds of farmlands and schools submerged (see plate 1,2,3and 4). Situated around the confluence of Niger and Benue Rivers, Niger state experiences severe flood episodes annually The Niger River, Benue and Gurara River overflows their channels annually during the rainy season as a result of the inability of the existing natural drainage system not being able to accommodate the accumulated water thereby causing damages. Rapid urbanization, land use planning activities and weak development control strategies including poor flood plain management are among the major factors responsible for increasing flood frequency, intensity and damages in the area. If planned well, assessment and recovery processes should provide better understanding of the local economy to determine how different interventions may affect it. (Action Aid International,2006a).

Abdul-Rahman, (2016), revealed that flood destroys two basic physical objects namely: human being and property. The two have always been the focus of study on disasters planning management. In light of this, response to flood disaster is either directly towards the affected persons or properties. Destruction of lives and properties, outbreaks of disease, displacement of people (homeless), hunger, thirst, and psychological imbalance among others are some of the concomitant effects of Niger State flood disasters. People's needs and the flood's impact are not linked solely to the level of water, and the conditions of their lives and livelihoods do not necessarily improve when the water recedes. Often, greater challenge starts when floodwaters recede and displaced people start returning home, which is when many agencies declare an end to assistance (ALNAP and Prevention, 2008a).Despite efforts taken by the governments at all levels, their agencies, the NGOs and the individuals concern in response to flood disasters; the recurrent events have followed almost the same pattern. For instance, in Niger State, buildings are still found on river/stream setbacks and floodable plains, emergency measures have always been inadequate, drainage systems are inadequate, some damaged infrastructure (such as access roads, bridges, culverts and electric poles) are still left to the affected neighbourhoods to replace, and noncompliance to town planning authority and building code still persist.

An effective owner-driven approach to flood response and recovery measures means that key decisions are taken by the owners and that NGOs and the government support their decisions with resources and technical inputs. An India Disaster Mitigation Institute (AIDMI, 2007).This study is predicated on the need to strengthen and institutionalize existing flood response and recovery measures in Niger state in view of the apparent past, weak, disjointed and ineffective efforts of various emergency agencies in the state during and after major flood disasters.

In each flooding episode, rescue and recovery operations remain ad-hoc in nature, haphazard, uncoordinated and apparently ineffective despite the huge resources devoted to such operation. This study seeks to evaluate the effectiveness of these operation and the sustainability issue 
PLATES 1, 2, 3, 4: Effects and Impact of Major Flood Events in the Study Area

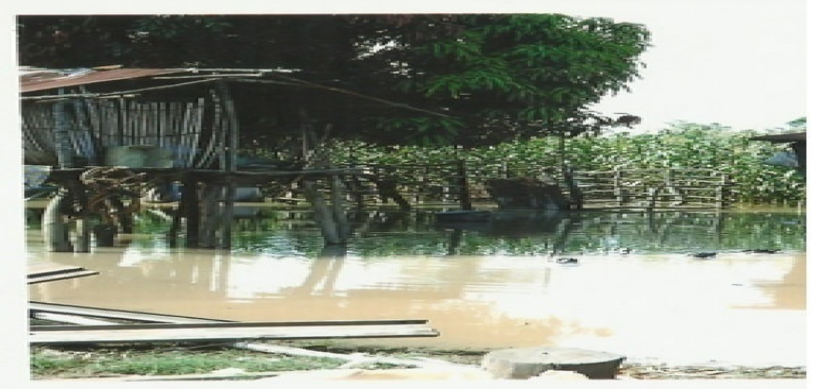

PLATE 1

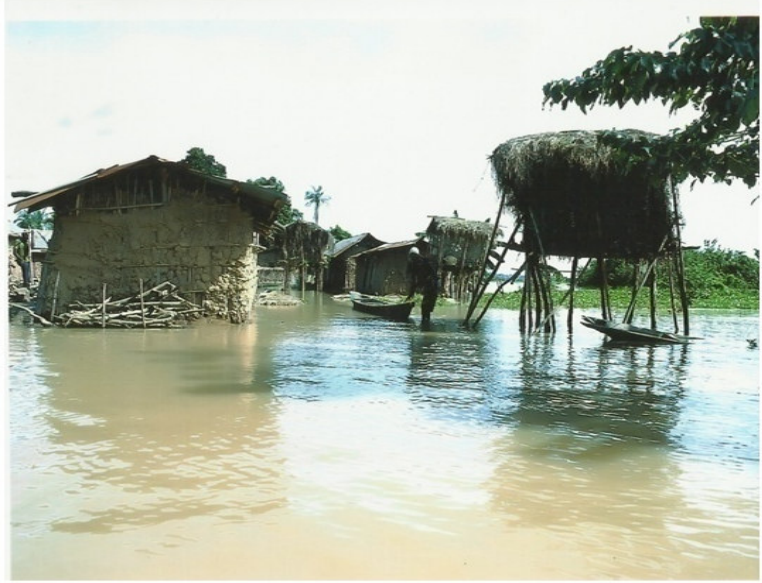

PLATE 3

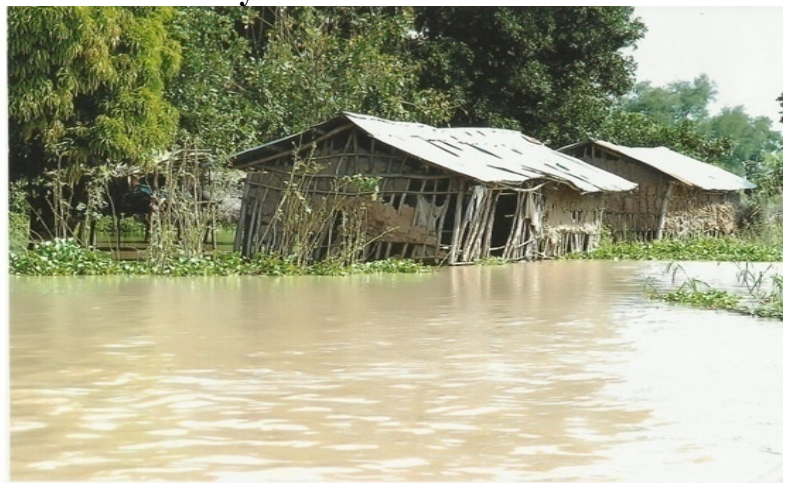

PLATE 2

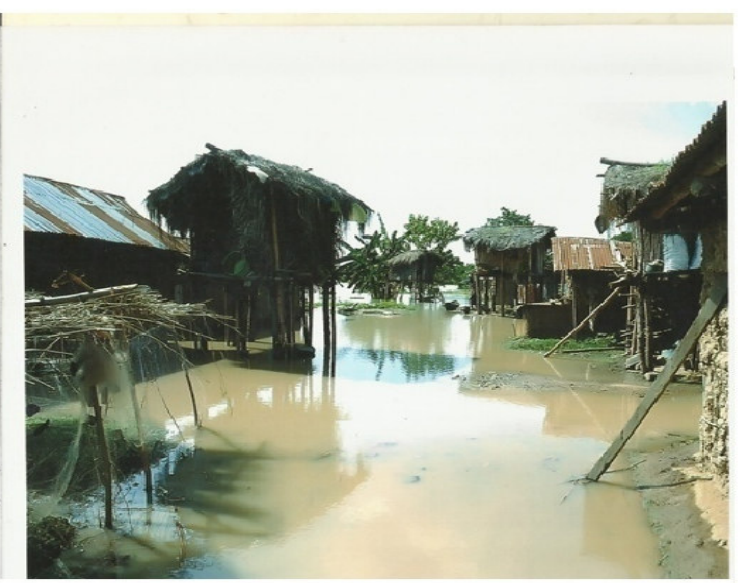

PLATE 4

Sources: Researcher's field survey 2019

\section{Objective of the study}

The study sought to achieve the following objective:

1. To identify formal and informal organisations involved in flood response and recovery measures during flood disasters in Niger state.

\section{Research question}

1. Which formal and informal organisations are involved in flood response and recovery measures during flood disaster in Niger state?

\section{Conceptual Framework And Systematic Review Of Related Literature}

For the purpose of this study, the concept that are directly related to response and recovery measures to flood disasters are emphasized. which include the theoretical framework for governance,

\section{The Theoretical Framework for Governance}

Numerous scholars have come up with definitions concerning the concept of governance. The unified interpretation seems to be, despite the multiple perspectives of the definitions, that as a term, governance refers to the political field and political activity as the vital task of every national government. At the outset, however, we would like to emphasize that the terms government and governance are not same. That is, government and governance are not synonymous terms, although both share goals-oriented objectives. Government occurs when those with legally and formally derived authority and policing power execute and implement activities; by contrast, governance refers to the creation, execution, and implementation of activities backed by the shared goals of citizens and organizations, who may or may not have formal authority or policing power (Ahem,Sari Kovats, Willkinso, Faw and Matthies 2010).

According to Graham (2003), government is bureaucracy, legislation, financial control, regulation, and force. Governance, on the other hand, refers more like to a growing use of non regulatory policy instrument. This 
policy instrument aspect focuses the attention towards proposed, designed, and implemented cooperation by non state actors working together with state actors UNDP (2003). As a whole, governance is a growing phenomenon. The literature on governance is definitely considerable and expanding Aminuzzaman (2010). Back in history, in the fourteenth century for instance, the term governance referred to an action, method, or function of governing Halfani (1994).

Landell et al. (2010), governance denotes how people are ruled, how the affairs of the states are administered and regulated, as well as a nation's system of politics, and how this functions in relation to public administration and law. According to Graham (2003), governance is seen as interaction among structures, processes, and traditions that determine how power and responsibilities are exercised, how decisions are taken, and how citizens and other stakeholders have their say. Therefore, governance is about power, relationship, and accountability: it addresses the questions like who has the influence, who makes the decisions, and how decision-makers are held accountable.

Halfani (1994) and Umar, T. I. (2017) highlight governance as a system of government concentrating on effective and accountable institutions, democratic principles and electoral process, representation and responsible structures of government in order to ensure an open and legitimate relationship between the civil society and the state. They emphasized on the relationship between the civil society and the state, which is very crucial. This is in fact and an important notion since this differentiates the study of governance from the study of government. The nature of the relationship between the civil society and the state is the most important feature in their definition. They believe that credibility and legitimating of government can be achieved effectively and efficiently through decentralization and sharing, people's participation, accountability, transparency, and responsiveness.

In the same way, Organization for Economic Co-operation and Development's (OECD) (1995) definition of governance includes public administration and the institutions, methods and instruments of governing and also incorporates relationship between government and citizen (including business and other citizen groupings) and the role of the state. In order to cope with the challenges of the twenty-first century, to understand the relationship in-between the state and non state agencies is thus important. This is because of the economic globalization, massive corruption of state agencies, failure of centrally planned economy, elitist bureaucracy, remarkable breakthrough of information technology, and the rising role of the third sector, popularly known as the Non-governmental Organizations (NGOs) across the developing world (e.g., Hossain 2001; Salomon and Anheier 1996; Anheier and Seibel 1990).

The UNDP (2002) further argues that good governance advances sustainable development for three reasons. Firstly, enjoying political freedom and participating in the decisions that shape one's life are fundamental human rights.

Secondly, it helps to protect people from economic and political catastrophes. And finally, because it can promote sustainable development by empowering citizens to influence policies that promote growth and prosperity and reflect their priorities Hope (2005). It needs to be pointed out from the above discussion that the notion of good governance is still developing in terms of its definition, its ethical connotations, and its usefulness Umar, T. I. (2017) In addition, critics suggest that the theory of good governance is often used as a tool - just as human rights and democracy - to gain advantage politically rather than to genuinely help the people.

Umar, T. I. \&Ihekwoaba, E.N.(2020) identified the deficiencies of the concept of good governance from two perspectives. For example, firstly, interaction of only three forces or elements are considered to constitute good governance - the interaction among the state, civil society, and the private sector. But the governance in developing countries is more influenced by global and regional forces rather than domestic forces. Secondly, the term "good governance" is heavily loaded by normative values - what is good and what is bad and for whom? as defined by global power politics. As a result, in order to meet and manage the challenges of globalization.

Umar, T. I.(2020) proposes the concept of "sound governance" in the place of "good governance." According to him (2020) sound governance means more than the term government and governing and good governance. Sound governance includes the state as an enabling institution, the constitutional framework, the civil society, the private sector, the engaged citizens, and the international/global institutional structure within limits. He further argues that it is "inclusive and promotes participation and interaction in an increasingly complex, diverse, and dynamic national and international environment Umar, T. I.(2020) Therefore, the meaning of good governance cannot be confined in a timeframe. Cultural heritage, traditional values, environmental realities, political culture, and economic structure have to be taken into account in defining and determining characteristics of good governance Umar, T. I. (2017). It is important to keep in mind that the condition of any development model may remain unrealized given the social economic, political, and cultural complexities of a particular society. The main challenges which arise from both the academic and aid agencies' models of governance is applicability in the cases of developing countries, where socio economic and political features are complex Haque (2011).

Farazmand (2013) highlights that "local regional and cultural distinctiveness demands application of 
governance models that are suitable to local conditions." For example, South Asia has a long colonial history and its administration has therefore been heavily influenced by the colonial rule. As a result, the administrative and political systems of South Asia are incompatible with its indigenous social, economic, political, and cultural contexts (Vartola. 2010, Haque 2011).

\section{Response and Recovery Measures}

Early actions (and their results) have a major impact on the recovery. Umar, T. I. (2017).. The tendency of people after a natural disaster is to band together ensuring that mutual trust can be maintained is important for effective reconstruction efforts. For example, the manner in which relief distributions are managed either enhances community involvement in reconstruction or constrains it, fostering dependency or worse Umar, T. I. (2017).. It is far harder to stop the use of force, looting, rioting and the firing of weapons than it is to prevent them in the first place. Similarly once violence against women begins to occur among victims, not only is it a tragedy, but the capacity to use women organizers to work with families when rebuilding needs to being may be lost. Investigations carried out by Umar, T. I.(2020) revealed disparities between rural and urban areas in recovery activities. Urban dwellers tend to be more politically powerful and vocal in pursuing emergency allocations, even when the damage is more severe in rural areas and poverty is also concentrated there Umar, T. I.(2020) Care, therefore, needs to be taken not to over-prioritize attention to the urban areas. It is often the case that the impacts of disaster are uneven, and marginalized groups need special attention Umar, T. I. (2017)

This arises from differences in income status, culture, gender, location and type of home, and land tenure. A common inequity occurs when the immediate needs of the poor are ignored in the immediate post-disaster period and they have to sell their productive assets, including especially their land to the better-off. This is less of a problem in rural areas where communal land tenure is still the rule. Umar, T.I.\& Ugwu, L. N.(2019.Both flood risk reduction and response are more likely to be effective when they include coping mechanisms in the assessment and programme design. (Bakar.2012). Vulnerable people individually and collectively develop their own means, resources and strategies to cope with flooding. All of these mechanisms, however, have financial, social and/or opportunity costs. A study carried out by Umar, T. I. (2017) revealed that community-level disaster preparedness planning that begins immediately after the relief phase reduces post-disaster anxiety. Support for mitigation activities is also required but the focus should be broadened to include non-structural measures, for example, supporting livelihood-related endeavours as a means of mitigating future disasters. (Nasiri.2013). Small-scale mitigation, teaching life-saving skills, contingency planning and even upgrading service provision are some key measures undertaken by non-governmental organizations (NGOs) and governments in Asia. (ALNAP and Prevention, 2008a). For many smaller NGOs, continuity of funding support is a critical limiting factor in maintaining their disaster preparedness (DP) work. Globally, some funding is available for disaster reduction, but little is left to support concrete action, beyond training and planning (IFRC 2002).

Flood early warning and forecasting in most parts of the world can produce information with longer lead times Umar, T. I. (2017) They are useful for both contingency planning and defining immediate actions in responding to a flood Umar, T. I. (2017) Poor people need early warning most, but many of them do not understand weather forecasting or the language of early warning. Early warning, however, has little relevance if people do not have ability to practice 'asset protection' as a key part of their flood response in Asia and Africa. Umar, T. I. (2017) These include supplying livestock fodder, restocking, livestock reconstructing community and household assets and distributing agricultural/business tools Umar, T. I. (2017)

Flood trends are changing and more frequent flooding impacts on cropping seasons, making people, food and livelihood insecure. Umar, T. I. (2017) In such cases, a possible response is to distribute alternative, nutritious varieties of seeds. Umar, T. I.(2020) The environment and ties to land are considered to be essential elements in the survival of indigenous societies and distinctive cultural identities.(Cannon.2006). The displacement and resettlement process has been consistently shown to disrupt and destroy those networks of social relationships on which the poor depend for resource access, particularly in times of stress. Umar, T. I.(2020) Migration is an ancient coping mechanism in response to environmental (and other) change and does not inevitably result in negative outcomes, either for the migrants themselves or for receiving communities Umar, T. I.(2020)

Effective flood responses are, therefore, those that build on people's existing ways of dealing with floods and complement their coping mechanisms, resources and social capital. Umar, T. I.(2017) In areas where flooding occurs regularly, the community will probably be better prepared than people living in places where floods are rare. Many flood-prone communities have local and traditional institutions dealing with disasters. As the flood season approaches in Sudan, for example, local community leaders on Tuti island, at the confluence of the White and Blue Nile, set up a flood control committee which is in charge of contingency planning, coordinating emergency operations and providing material assistance. (IFRC 2002). Unless affected people are involved- and not merely consulted- in determining their needs and in participating in project design and management, the impact of emergency or long-term interventions is likely to be limited. (ALNAP,2003) 
According to an Action Aid impact review, the agency's normal principles, such as participation and gender analysis, were considered difficult to integrate in an emergency in countries with less emergency experience. (Action Aid,2006). Following the Mozambique flood in 2000, the World Bank highlighted that consultation improved the nature of the interventions, but participation leading to empowerment was rare, mainly due to the lack of transparency and equity between negotiating bodies. Umar, T.I.\& Ugwu, L. N.(2019If planned well, assessment and recovery processes should provide better understanding of the local economy to determine how different interventions may affect it. (Action Aid International,2006a). An evaluation in Wajir, Kenya after the drought and flood in 1996-1997 noted that relief distribution had stabilized food prices, thus shoring up pastoralists' purchasing power. But, for example, excessive cash distributions over a period of time may also affect the local economy negatively by causing inflation. (Action Aid International,2006b). Support to local market activity can broaden the base of livelihoods programmes and tap community resources for flood response, although such measures must be carefully designed. For example, markets are dynamic and must be monitored over time and space. According to the World Food Programme (WFP,2006), the livelihood of the local markers of clay roofing tile was severely affected when agencies distributed metal sheeting in the 2000 flood response in Bangladesh. (WFP,2006). Some agencies have therefore responded to flood disasters by including economists and market analysts on their staff . (WFP,2006).

Considering improvement of water system and sanitation, the literature shows that past relief and recovery operations have identified a range of approaches which include: incorporating mitigation measures during the rehabilitation of water, sanitation and health systems for future protection Umar, T. I.(2017) strengthening health volunteer networks to enhance their effectiveness in emergency preparedness and response Umar, T. I.(2017) raising tube-wells and boreholes above floodwater level to prevent contamination; including buckets and water containers in relief packages to reduce secondary contamination, planning sanitation and shelter together to ensure completion Umar, T. I.(2017)

Attention to placement and arrangement of sanitary facilities to limit impact on ground water and ensure safety for community members; innovative approaches to sanitation in flooded areas, such as raised latrines, pit liners or rings, sealed pits or tanks, or contained leach fields Umar, T. I.(2017) ); and extending hygiene education to schools and to community groups. Umar, T. I.(2017) According to Umar, T. I.(2017) , public health and health care services required for preventing adverse health impacts from an extreme weather event include surveillance and control activities for infectious disease, access to safe water and improved sanitation, food security, maintenance of solid waste management and other critical infrastructure, maintenance of hospitals and other health care infrastructure, provision of mental health services, sufficient and safe shelter to prevent or mitigate displacement, and effective warning and informing systems. Umar, T. I.(2017) Strategies for post-flood housing programmes need to be based on the impact of flooding on houses and their long-term consequences, (ALNAP and Prevention, 2008a) rather than on the standard housing cycle concept (transitional to permanent housing).

The response needs to cover affected people's immediate survival needs up to the point at which durable solutions are reached. Quick provision of temporary shelter reduces exposure, can help to limit the outbreak of disease and allows people to move quickly out of community shelters, which may be needed for schooling or other community facilities. Reconstructing permanent housing in large-scale disasters may take a long time. In such cases, temporary or transitional shelter should have adequate facilities (for water, sanitation and cooking). Umar, T. I.(2017) and a system should be in place to monitor conditions of shelter. Umar, T. I.(2020) Preferences in housing vary by sex and age. An effective owner-driven approach means that key decisions are taken by the owners and that NGOs and the government support their decisions with resources and technical inputs Umar, T. I.(2020)

\section{THE STUDY AREA}

\section{Administrative and Geographical Location}

Niger state geographically lies between $8^{\circ} 00^{\prime} 0^{\prime \prime}$ to $11^{\circ} 30^{\prime} 0^{\prime \prime}$ in latitude Northing and $3^{\circ} 30^{\prime} 0^{\prime \prime}$ to $7^{\circ} 30^{\prime} 0^{\prime \prime}$ in Longitude Easting. It is border to the North by Zamfara State, West by Kebbi state, south by Kogi state and south-West by Kwara State, Kaduna and Federal capital Territory boarder the state to both North-East and South-East respectively. The state has a boundary with Republic of Benin along New -Bussa, Agwara and Wushishi local Government Area. This has given rise to common inter border trade between the two counties Umar, T. I.(2020) (figure 3.1). 


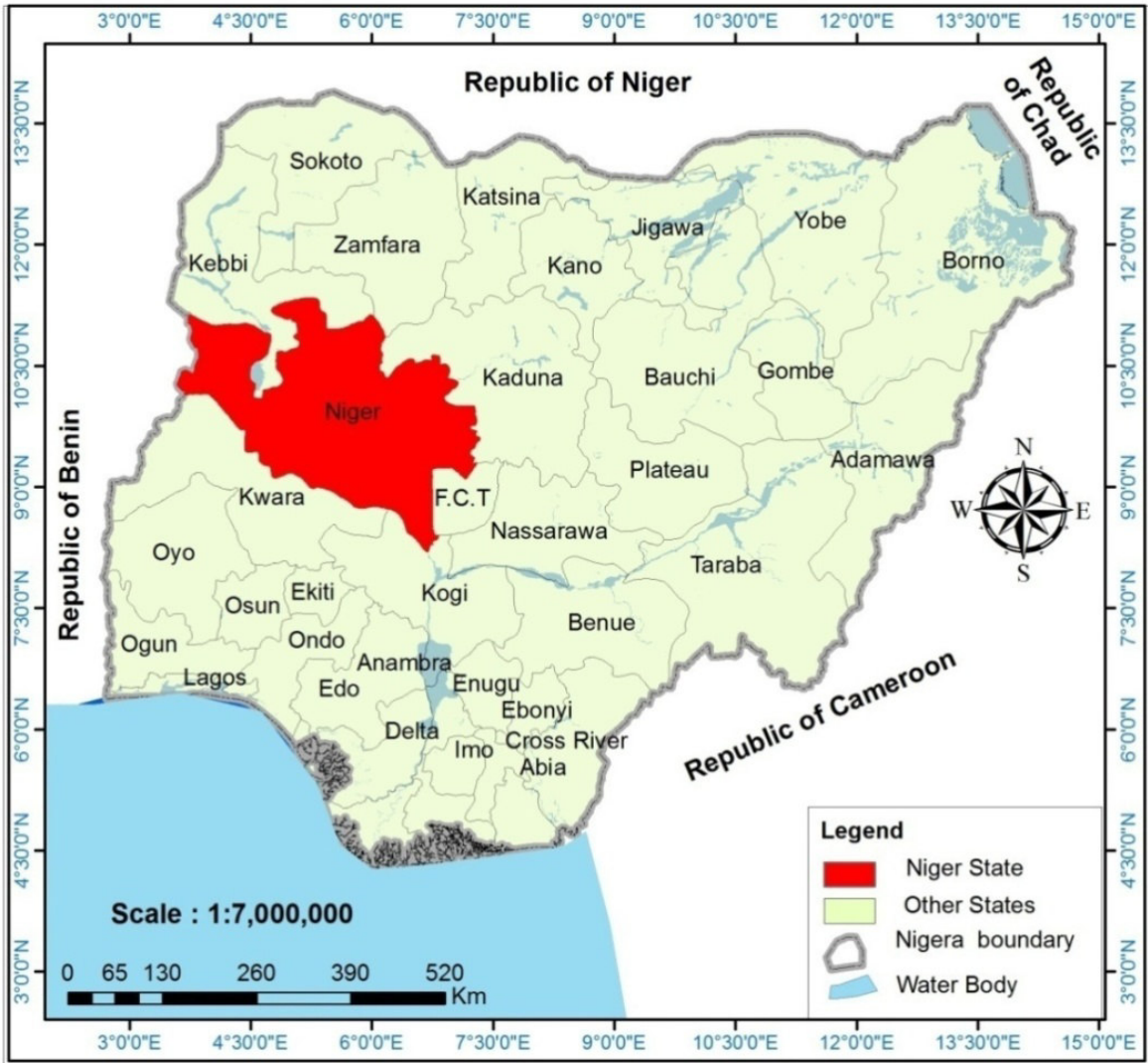

Figure 3.1: Map of Nigeria Showing Niger State.

Source: Federal University of Technology, Minna (2019)

Niger State has Minna as its capital. Other major cities are Bida, Kontagora, and Suleja. Located in the Middle Belt of Nigeria, Niger State covers 76,363 square kilometres. It is the largest Nigerian state by land area . It consists of 25 local government areas which include Agwara, Agwara, Borgu, Mashegu, Kontagora, Wushishi, Rafi, Magama, Mariga, Tafa, Munya, Suleja, Gurara, Bida, Lapai, Agaie, Gbako, Edati, Katcha, Chanchaga, Bosso, Paikoro, Lavun, Mokwa, Shiroro, Rijau, (figure 3.2) 


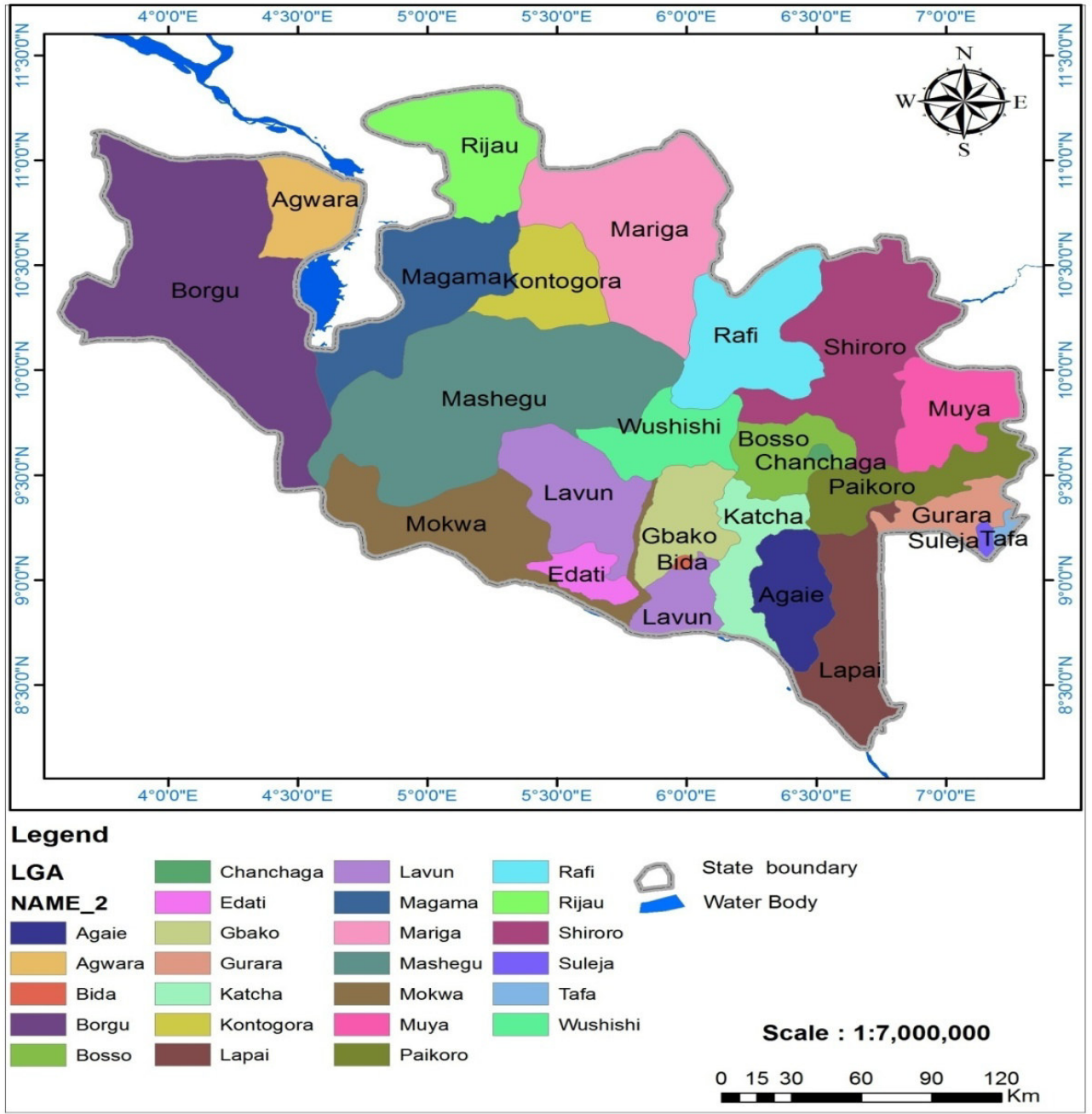

Figure 3.2: Map showing the different local government in Niger State

Source: Federal University of Technology, Minna (2019)

\section{Research Methodology}

Survey research design was adopted. Both qualitative and quantitative data collection were used. Collection of qualitative data was through oral interviews and non-participant observation, while quantitative data were collected using structured questionnaire and secondary sources such as books and journal articles. The oral interview targeted key senior member involving flood disaster management team. Interview was conducted based on questions drawn from prepared interview guide and recorded manually. The non-participant observation data were derived using observation schedule and photographic material during several visits made to the site. Due to the constraints, study avoided inclusion of residents and visitors to the scheme in the interview schedules for probable need to ascertained and confirm the observed data and inferences

\section{Research Findings}

Data presentation for the computation of formal and informal organizations involved in flood response and recovery measures during flood disasters in Niger state were also evaluated and interpreted. The Kaiser-MeyerOlkin (KMO) which measures the sampling adequacy (that is if the responses given with the sample are adequate or not) have a value of 0.644 , which is higher than 0.5 and therefore can be accepted indicating that the sampling is adequate for the component analysis. Also, the result showed the Bartlett's test which is another indication of the strength of the relationship among variables. The Bartlett's Test of sphericity is with the value of .000 is significant as it is less than 0.05 . In fact, it is actually showed that 0.000 is significantly small enough to reject the null hypothesis. This means that correlation matrix is not an identity matrix.

The communalities which also shows how much of the variance (i.e. the communality value which should be more than 0.5 to be considered for further analysis or else the variables are to be removed from further steps factor analysis) in the variables has been accounted for by the extracted factors indicated that $72.9 \%, 87.8 \%$, $93.1 \%$ and $96.0 \%$ of the variance in Neighbours/family/friends, Community NGOs 
/Association/Cooperatives/Religious bodies, Local/Niger state government including NIGSEMA and Federal government agencies/Security forces/ FEMA/International Organization is accounted for. The Eigen value which reflects the number of extracted factors whose sum should be equal to number of items subjected to factor analysis indicated that three factors or components and the cumulative percentage was $73.89 \%$. This implies that the three factors explained $73.9 \%$ of the variance. The table 5.13 above shows the loadings (extracted values of each item under 3 variables) of the eight variables on the three factors extracted. The higher the absolute value of the loading, the more the factor contributes to the variable (Three variables were extracted wherein the 5 items are divided into 3 variables according to most important items which similar responses in component 1 and simultaneously in component 2 and 3 ). The idea of rotation is to reduce the number factors on which the variables under investigation have high loadings. Looking at the table above, neighbours/family/friends, Local/Niger state government including NIGSEMA and Federal government agencies/Security forces/ FEMA/International Organization are substantially loaded on Factor (Component) 1, 2 and 3 respectively. All the remaining variables are substantially loaded on Factor.

\section{Decision}

Since the p-value $=.000$ from KMO and Bartlett's Test part of the output from table 5.13 (which is an identity matrix), reject the null hypotheses and accept the alternate hypotheses. Therefore, we conclude that neighbours/family/friends, Local/Niger state government including NIGSEMA and Federal government agencies/Security forces/ FEMA/International Organization are the formal and informal organizations involved in flood response and recovery measures during flood disasters in Niger state.

Table 5.9 Communalities

\begin{tabular}{|l|r|r|}
\hline & Initial & Extraction \\
\hline Neighbours/family/friends & 1.000 & .729 \\
Community NGOs /Association/Cooperatives/Religious bodies & 1.000 & .878 \\
External religious bodies/Red cross/NGOs/Philanthropic organizations & 1.000 & .196 \\
Local/Niger state government including NIGSEMA & 1.000 & .931 \\
Federal government agencies/Security forces/ FEMA/International Organization & 1.000 & .960 \\
\hline
\end{tabular}

Extraction Method: Principal Component Analysis.

$$
\text { Initial Eigen values } \quad \text { Extraction Sums of Squared Loadings }
$$

Component Total \% of Variance $\quad$ Cumulative \% $\quad$ Total $\quad \%$ of $\quad$ Cumulative \%

\begin{tabular}{rrrrrrr} 
& & \multicolumn{3}{c}{ Variance } \\
\hline 1 & 1.578 & 31.558 & 31.558 & 1.578 & 31.558 & 31.558 \\
3 & 1.079 & 21.572 & 53.130 & 1.079 & 21.572 & 53.130 \\
4 & 1.038 & 20.763 & 73.893 & 1.038 & 20.763 & 73.893
\end{tabular}

$\begin{array}{rrrr}4 & .941 & 18.818 & 92.711 \\ 5 & .364 & 7.289 & 100.000\end{array}$

Table 5.11 Total Variance Explained

\begin{tabular}{lrrrr}
\hline Component & \multicolumn{3}{c}{ Rotation Sums of Squared Loadings } \\
\%o of Variance & \multicolumn{2}{c}{ Cumulative \% } \\
\hline 1 & Total & & 30.146 & 30.146 \\
2 & 1.507 & 1.106 & 22.125 & 52.271 \\
3 & 1.081 & 21.622 & 73.893 \\
\hline
\end{tabular}

Extraction Method: Principal Component Analysis.

Table 5.12 Component Matrix ${ }^{\mathrm{a}}$

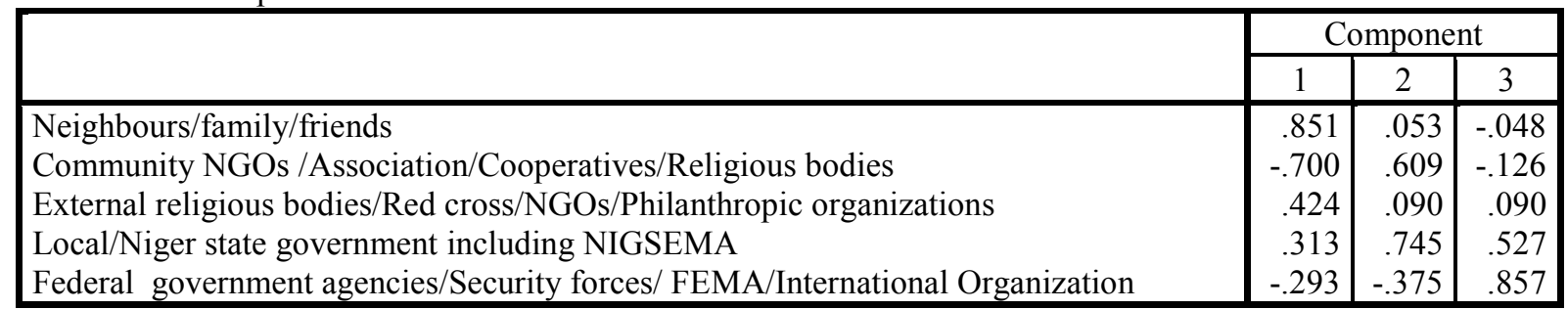

Extraction Method: Principal Component Analysis. ${ }^{\mathrm{a}}$

a. 3 components extracted. 
Table 5.13 Rotated Component Matrix ${ }^{\mathrm{a}}$

\begin{tabular}{|l|r|r|c|}
\hline & \multicolumn{2}{|c|}{ Component } \\
\cline { 2 - 3 } & \multicolumn{1}{|c|}{1} & \multicolumn{1}{c|}{2} & \multicolumn{1}{c|}{3} \\
\hline Neighbours/family/friend & .765 & .253 & -.283 \\
Community NGOs /Association/Cooperatives/Religious bodies & -.883 & .246 & -.196 \\
External religious bodies/Red cross/NGOs/Philanthropic organizations & .369 & .235 & -.070 \\
Local/Niger state government including NIGSEMA & .067 & .962 & .050 \\
Federal government agencies/Security forces/ FEMA/International Organization & -.057 & .037 & .978 \\
\hline
\end{tabular}

Extraction Method: Principal Component Analysis.

Rotation Method: Varimax with Kaiser Normalization. ${ }^{\text {a }}$

a. Rotation converged in 6 iterations.

Evaluation of Activities Rendered By Friends, Family Members and Neighbours

Activities Involved by the neighbours, friends/families during flood disasters In Niger state were evaluated and interpreted. The KMO which measures the sampling adequacy (that is if the responses given with the sample are adequate or not) have a value of .707 which is higher than 0.5 , it is therefore accepted, indicating that the sampling is adequate for the component analysis. Also, the result showed the Bartlett's test which is another indication of the strength of the relationship among variables. The Bartlett's Test of Sphericity with the value of .000 is significant as it is less than 0.05 . It implies that actually 0.000 is significantly small enough to reject the null hypothesis. This means that correlation matrix is not an identity matrix. The communalities which also shows how much of the variance (i.e. the communality value which should be more than 0.5 to be considered for further analysis, otherwise the variables are to be removed from further steps factor analysis) in the variables has been accounted for by the extracted factors which indicated that $50.7 \%, 62.3 \%, 65.5 \%, 70.4 \%, 80.4 \%, 66.1 \%$, $82.6 \%$ and $96.0 \%$ of the variance in shelter, food, medicine, psycho, employment, skill and transportation as well as resumption of normal life were accounted for respectively.

The Eigen value which reflects the number of extracted factors whose sum should be equal to number of items subjected to factor analysis indicated that four factors or components were extracted and the cumulative percentage was $64.710 \%$. This implies that the three factors explained $64.710 \%$ of the variance. The table 5.17 below shows the loadings (extracted values of each item under 4 variables) of the nine variables on the four factors extracted. The higher the absolute value of the loading, the more the factor contributes to the variable (Four variables were extracted wherein the 9 items are divided into 4 variables according to most important items which similar responses in component 1 and simultaneously in component 2, 3 and 4). The idea of rotation is to reduce the number factors on which the variables under investigation have high loadings. Looking at the table5.17 shelter, food, medicines, psycho-social support, employment, skill and resumption of normal life are substantially loaded on Factor (Component). This indicates the activities that neighbours were actively involved. All the remaining variables are substantially loaded on Factor.

Therefore, it is concluded that neighbours/family/friends, were actively involved in the provision of shelter, food, medicines, psycho-social support, employment, skill and resumption of normal life in flood response and recovery measures during flood disasters in Niger state.

Table 5.14 Communalities

\begin{tabular}{|l|r|r|r|}
\hline & \multicolumn{2}{|c|}{ Initial } & Extraction \\
\hline Shelter & & 1.000 & .507 \\
Food & & 1.000 & .623 \\
Medicine & 1.000 & .655 \\
Psycho & 1.000 & .704 \\
Employment & & 1.000 & .804 \\
Financial & 1.000 & .396 \\
Skill & 1.000 & .661 \\
Transportation & & 1.000 & .826 \\
Resumption & 1.000 & .649 \\
\hline
\end{tabular}

Extraction Method: Principal Component Analysis. 
Table 5.15 Total Variance Explained

\begin{tabular}{|l|r|r|r|r|r|r|}
\hline \multirow{2}{*}{ Component } & \multicolumn{3}{|c|}{ Initial Eigen values } & \multicolumn{3}{|c|}{ Extraction Sums of Squared Loadings } \\
\cline { 2 - 7 } & Total & \% of Variance & Cumulative \% & Total & \% of Variance & Cumulative \% \\
\hline 1 & 2.392 & 26.582 & 26.582 & 2.392 & 26.582 & 26.582 \\
2 & 1.300 & 14.450 & 41.032 & 1.300 & 14.450 & 41.032 \\
3 & 1.086 & 12.070 & 53.102 & 1.086 & 12.070 & 53.102 \\
4 & 1.045 & 11.608 & 64.710 & 1.045 & 11.608 & 64.710 \\
5 & .824 & 9.159 & 73.869 & & & \\
6 & .771 & 8.569 & 82.438 & & & \\
7 & .673 & 7.482 & 89.919 & & & \\
8 & .481 & 5.341 & 95.260 & & & \\
9 & .427 & 4.740 & 100.000 & & & \\
\hline
\end{tabular}

Table 5.16 Total Variance Explained

\begin{tabular}{|l|r|r|r|}
\hline \multirow{2}{*}{ Component } & \multicolumn{3}{|c|}{ Rotation Sums of Squared Loadings } \\
\cline { 2 - 4 } & Total & \% of Variance & Cumulative \% \\
\hline 1 & 2.366 & 26.293 & 26.293 \\
2 & 1.246 & 13.840 & 40.132 \\
3 & 1.110 & 12.338 & 52.470 \\
4 & 1.102 & 12.240 & 64.710 \\
\hline
\end{tabular}

Table 5.17 Component Matrix ${ }^{\mathrm{a}}$

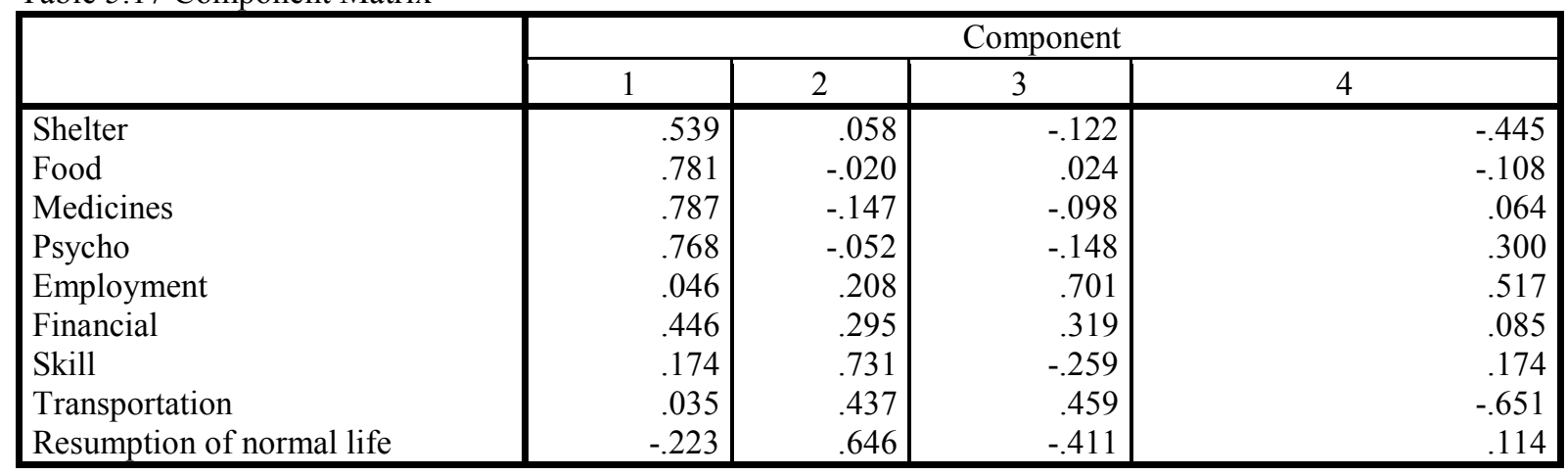

Extraction Method: Principal Component Analysis. ${ }^{a}$

a. 4 components extracted.

Table 5.18 Rotated Component Matrix ${ }^{\mathrm{a}}$

\begin{tabular}{|c|c|c|c|c|}
\hline & \multicolumn{4}{|c|}{ Component } \\
\hline & 1 & 2 & 3 & 4 \\
\hline Shelter & .538 & .011 & .373 & -.280 \\
\hline Food & .769 & -.057 & .163 & .032 \\
\hline Medicines & .802 & -.077 & -.079 & .007 \\
\hline Psycho social support & .787 & .077 & -.249 & .129 \\
\hline Employment & -.048 & -.034 & -.005 & .894 \\
\hline Financial & .384 & .124 & .241 & .418 \\
\hline Skill & .163 & .785 & .071 & .115 \\
\hline Transportation & -.062 & .037 & .902 & .090 \\
\hline Resumption & -.206 & .772 & -.023 & -.100 \\
\hline
\end{tabular}

Extraction Method: Principal Component Analysis.

Rotation Method: Varimax with Kaiser Normalization ${ }^{a}$

a. Rotation converged in 5 iterations. 


\section{Recommendation/Conclusion}

The recommendations are divided into two 'policy and practical recommendations'. On the account of policy recommendations, the need to protect the immediate environment, the human population and livelihoods from recurrence of unmitigated flood disasters should be embedded in a program of actions adopted by the government at all levels as well as NGOs. To lessen the effect and impact of flood on the lives and property of the state's citizenry and the nation in general, policy makers need to shift resources and policy actions towards proactive measures on emergency/disaster reduction with two of the cardinal tools of emergency management: namely preparedness and mitigation. It is apparent that recovery measures would not restore the lives and properties lost during flood disasters. In fact, any attempt toward recovery would only be achieved by using resource that could have been used for further development if the disaster had been prevented or prepared for. With additional investments in flood disaster management, significant improvements in disaster and response are achievable. While the following recommendation have been made before, little has been done to implement them, thus they are worth repeating.

There is need to establish a multi-disciplinary national centre and regional chapters to focus on vulnerability. Efforts that will help develop and improve the data, methods, and models for understanding flood vulnerability and more importantly, developing tools and strategies for improving nation's resiliency to future flood occurrences. The planning and preparedness includes the period before a disaster. Activities should also include the development of plans and participation in local, regional or state-wide training exercises. Flood disaster plans need to include the role of the hospital or health centre as a survivor and as a responder. Plans need to address internal lines of authority and action. This also includes provision of appropriate training for staff and at least an annual update or revision of flood disaster plans and a comprehensive review of the plan with all staff.

Secondly, the research suggests provision of tool-box of data and procedures for local communities to reduce the preparedness divide and also create a more uniform baseline across the Nation especially with placebased flood vulnerability assessments. Similar to this, there is need to increase governments support of rapid response research to secure critical social science and geo-spatial data and information in disasters.

Finally on the aspect of policy recommendations, as a nation, we need to understand the human decision and organizational failures that contributed to the flood disaster that affected twenty- Seven (27) states in 2017 including Niger state so that it won't happen again. There is immediate need for a dependent review of the local, state and federal response to flood events so that we can learn the lessons of what went right and what went wrong in the response and use these to improve our preparedness and responses to future disasters.

The second set of recommendations is the practical-oriented rather than policy-oriented. Firstly the issue of public enlightenment and awareness need to be extended in practical sense. The state owned radio station in Niger state and the National Television Authority (NTA) have been sensitizing the people on the danger of dumping refuse inside the rivers. The jingle played in English, pidgin and local dialects always ends in prayer that God will spare the people from another disaster trauma again. There is need to improve on this strategy.

Another area of practical recommendation is management of drains. Efforts should be made on a long- term basis, to completely characterized Kuchi River just as the Shiroro River is at present. On a short term basis, however, all the major rivers and streams in the study area should be dredged and channel on a periodic basis. If possible, this should be done every year, preferably in march / April at the beginning of the rainy.

\section{REFERENCES}

Abdulrahman A. (2016) flood Displaces,500,000 people in Niger state. Daily Trust. 73(40).

Action Aid International (2006a) Emergencies impact review, Action International Aid, London. Available at www.reliefweb.int/rw.lib.nsf/db900SID/LGEL 5E6ATQ/\$FILE/actionaid-imapact-mar02.pdf?openElement (Retrieved in September, 2016).

Adedeji, O.H, Odufuwa, B.O, and Adebayo O.H. (2012) “Building Capabilities for Flood Disaster and Hazard preparedness and risk reduction in Nigeria: need for spatial planning and land management", Journal of Sustainable Development in Africa, 14(1):1-5. Pennsylvania: Clarion University of Pennsylvania. Clarion.

ALNAP and Prevention (2008a) Slow onset Drought and food and Livelihoods insecurity from previous Relief and Recovery responses. www.alnap.org/publications/pdfs/ALNAPProvention_lessons_on_slow_onset_disaster.pdf retrieved in June, 2016)

ALNAP and Preventions (2008b) Flood disasters: learning from Previous relief and recovery operations. Available at (retrieved in june,2012 www.alnap.org/publications/pdfs/ALNAPProvention_lessons_on_flood_disaster.pdf (retrieved in June, 2016)

An India Disaster Mitigation Institute (AIDMI) (2007) 2007 floods in south Asia: from impact to knowledge. Special issue 39, Delhi: An India Disaster Mitigation Institute available at www.southasiadisaster.net/downloads/snet\%39\%20sadnet\%20Bihar\%20flood\%202007.pdf (Retrieved in 
September, 2016)

Aminuzzaman S.M. (2010) Governance and development discourse in Bangladesh: a diagnostic assessment of challenges and concerns, In: Vartola J. Isom Asaduzzaman M.(eds) Towards good governance in SouthAsia. Tampere University Press, Tampere, 34:19-24

Ahem, M., Sari Kovats, R., Willkinso, F., Faw, R, and Matthies, F.(2010). "Global Health Impacts of Floods: Epidemiologic Evidence”Available at http://m.epirev.oxfordjournals.org/comant/27/1/36.full (Retrieved in September, 2012)

Bailey D.K. (1982) "Methods of Social Researcher New York: the Free Press.

Bakar,J.L. (2012) Climate change, disaster risk and the urban poor: cities building resilience for a changing world, world Bank Publications, Washington, Dc.

Bell-Gam, W.I.(2000) Introduction to Flood and Erosion. Unpublished Manuscript. the center For Urban and Community Studies, University of Toronto, Toronto.

Faniran, A (1975) The extent profile and significance of Deep in wreathing Nigeria journal of Tropical Geography 38 (1):19- 30.

Faniran, A. (1994) Relief and Draining in Filani M. O Akitola, F O and Ikporukpo, C. O. (eds), Ibadan Region; Rex Charles publications.

Farazmand A (2013) Governance in the age of globalization: challenges and opportunities South and South East Asia. Public Org Rev 13:349-363

Graham (2003) Governance principles on protected areas in the 21st century. A discussion paper Institute on Governance, the Fifth World Bark Congress, Dublin

Ghosh S.N, (2006b) Flood Wave Modification, along a prismate river, Water Resources Research: Geographical Union, 17(3): 697-703

Global Facility for Disaster Reduction and Recovery (GFDRR). (2011) sustainable Recovery financing facility (track111) global facility for disaster Reduction and recovery

Halfani M. (1994) Towards and understanding of governance: the emergency of an idea and its implication for urban research in developing countries. The Center for Urban and Community Studies, University of Toronto, Toronto

Haque SKTM (2011) The normative roots of governance theories: prospects and challenger fromBangladesh perspectives. In: Jamil I et al (eds) Understanding governance and public policy in Bangladesh. NorthSouth University, Bangladesh, 5(9-3): 47-70

Hope KR (2005) Towards good governance and sustainable development: the African peer review mechanism. Int J Policy Adm Inst 18(2):283-311

Hualou, L. (2011) disaster prevention and management A Geographic perspective disaster advances, 4(1): 45-72

International Federation of Red Cross (IFRC) (2002). Sudan: from risk to opportunity, flood risk reduction, case study. Geneva International federation of Red cross and Red Crescent societies.

Intergovernmental Panel on Climate Change (IPCC) (2007b) Fourth assessment report Geneva: intergovernmental panel on climate change.

Jacobson,M.,Webster, M. and Vairavamoorthy, K.(2012) The Future of Water in African Cities: Why Waste Water? World Bank, Washington, D.C

Landell M.P (2010) Governance and external Factors. In; Proceeding of World Bank annual conference on development economics, World Bank, Washington,DC

Mc Carthy, J., Canziani, O., Leary, N., Dokken, D., and white, K., (eds.),(2001) Climate change 2001: Impacts, adaptation, and vulnerability. Working group II of the intergovernmental panel on climate change, Cambridge: Cambridge University Press.

Nasiri,H. and Shahmohammadi, K.S.(2013) 'Flood vulnerability index as a knowledge base for Flood risk assessment in urban area' Journal of Novel Applied science 2:269-272.

United Nations Development Programme (UNDP) (2002) Human development report, deepening democracy in fragmented world. Oxford University Press, New York www.magnet.undp.org/Docs/cricis7monograph.htm. Accessed 2 Sep 2017

Rhetti butler (2009)"Cities and Urban Areas in Nigeria with population over 100,000", Retrieved from http://www.mongabay.com/igapo/nigeria.htm on 5th October, 2012. (retrieved in September, 2016)

National Emergency Management Agency (NEMA) (2012) Flood: more than 25,000 displaced in Benue as many communities remain adamant. National Emergency Management Agency. Available at http://www.nema.gov.ng/ emergency-zones/floods.aspx (retrieved in February, 2016)

Organization for Economic Co-operation and Development's (OECD) (1995) Governance in transition: public management in OECD countries. OECD, Paris

United Nations, (UN) (2018) World confederation for physical therapy,11 Belgrave Road. London SWIVIRB. UK 3(1):45-49.

United Nations Development Programme (UNDP) (2004) Reducing disaster risk: A Challenge for Development. 
United Nations development programme, bureau for crises and recovery.

Umar, T. I. (2017) An Analysis of the Degree of quality of indigenous building materials used in Lapai local Government Area of Niger state. Nigeria. International Journal in Physical and Applied Sciences http/www.ijmr.net 04: 34-45 .

Umar T.I \& Oduwole O. (2017) Enhancing Housing Affordability through effective utilization of indigenous building material Case study Lapai Local Government Area of Niger State International journal in commerce, IT and Social Science. 4: 19-3

Umar, T.I.\& Ugwu, L. N.(2019) Water And Sanitation Practices in Lokoja, Kogi State, Nigeria Advance Journal of Current Research Adv. J. C. Research Volume: 4; Issue: 12 ISSN: 2323 - 1744 Impact Factor: 3.178

Umar, T. I. \& Ihekwoaba, E.N.(2020) Solid Waste Management in Lokoja, Kogi State Nigeria Journal of Environment, Earth Sciences and Ecology Vol.02, No.01; January - Febrary-2020 p -ISSN (7304 - 490X); ISSN (2202 - 3011) Impact factor: 0.00

Umar, T. I.(2020) The Characteristic of The Rural Poor in Ebbo/Kuchi in Lapai Local Government Area of Niger State, Nigeria International Research Journal of Human Resource and Social Sciences ISSN(O): (2349-4085) ISSN(P): (2394-4218) Impact Factor 5.414 Volume 7, Issue 01, January 2020

Vartola J et al (2010) Towards good governance in South Asia: an introduction. In: Vartola J, Lumijarvi I, Asaduzzaman M (eds) Towards good governance in South Asia. University of Tampere Press, Finland

World Commission on Environmental and Development (WCED) (1987) Our common future, world commission on environmental and development (the brundtland commission). Oxford: oxford university press.

World Food Programme (WFP) (2006). Emergency needs assessments and the impact of food aid on local markets. C Donovan, M Mc Glinchy, J staatz and D Tschirley, SENACProject,WFP/EmergencyNeedsAssessmentBranch,documents.wfp.org/stellent/groups/public/docum ents/ena/wfp086537.pdf. (accessed 20 ${ }^{\text {th }}$ Oct. 2016).

Yamin, F. (2007) Assessing Key Vulnerabilities and the risk from climate change. In: Parry, M. 1., Canziani, O. F., Palutikof, J. P., Linden, P. J., Hanson, C. E. (eds), climate change 2007: impacts adaptation and vulnerability. Contribution of working group ii to the fourth assessment report of the intergovernmental panel on climate change, Cambridge: Cambridge University Press: 779-810. 